\title{
A compreensão do art. 10 do Novo Código Florestal à luz do Marco Jurídico-constitucional Socioambiental: caminhos hermenêuticos para uma gestão sustentável do Pantanal Mato-grossense'
}

\author{
Adriano Braun \\ Mestre em Direito pela Universidade Federal de Mato Grosso. Graduado em Direito \\ pela Universidade Federal de Mato Grosso.
}

\begin{abstract}
Sumário: 1. Introdução. 2. Pantanal Mato-grossense: sociobiodiversidade e conflitos socioambientais; 3. Os impactos do Novo Código Florestal sobre o Pantanal; 4. O Marco Jurídico-constitucional Socioambiental; 5. $\mathrm{O}$ art. 10 da Lei n. 12.651/2012 à luz do Marco Jurídico-constitucional Socioambiental; 6. Considerações Finais; 7. Referências.
\end{abstract}

\section{Introdução}

A confluência de diversos fatores econômicos, sociais, políticos e culturais articulados em nível mundial provocou, a partir das últimas décadas do século XX, uma crise ambiental sem precedentes na história da humanidade, que se manifesta de modo peculiar nos mais diferentes locais do planeta.

No caso do Pantanal, esta conjuntura se corporifica nas externalidades negativas resultantes do avanço de atividades econômicas altamente degradadoras, sobretudo nos planaltos circunvizinhos, gerando graves perturbações no delicado equilibrio ecológico da planície alagável.

Assim, não obstante o Pantanal seja direta e indiretamente contemplado por diversas normas jurídicas — internacionais, nacionais e estaduais estas não têm sido suficientes para evitar os profundos danos ambientais ocorridos neste bioma.

1 A maior parte das considerações delineadas neste artigo foram extraídas da dissertação de mestrado intitulada A dimensão socioambiental da crise civilizatória e as possibilidades legais para a efetivação de uma gestão sustentável do Pantanal Mato-Grossense formulada e defendida por este autor como requisito para a obtenção do título de mestre, no Programa de Pós-graduação em Direito Agroambiental da Faculdade de Direito da UFMT. 
Nesse contexto, os povos e comunidades tradicionais que habitam a região têm enfrentado graves dificuldades. Diretamente afetados pelos desequilibrios ecológicos, essas populações — quando não são totalmente desconsideradas - são encaradas como entraves ao progresso social e econômico, sendo-lhes negado o direito de participar ativamente nos processos decisórios atinentes à gestão do espaço que lhes pertence e que conservam há inúmeras gerações.

Este quadro tende a se agravar com a entrada em vigor do Novo Código Florestal, que, ao flexibilizar as regras atinentes à definição das APPs, tornou possível que parcelas consideráveis da planície alagável sejam exploradas economicamente.

No entanto, é possível e viável a formulação de novos caminhos hermenêuticos aptos à construção de cenários alternativos, sobretudo com base nos ditames constitucionais concernentes à proteção integrada dos bens naturais e culturais, articulada à participação popular.

Sendo assim, com base em algumas das reflexões empreendidas por Juliana Santilli e Carlos Frederico Marés, este ensaio pretende uma releitura do art. 10 do Novo Código Florestal a partir do Marco Jurídico-constitucional Socioambiental - conforme delineado por Ingo Wolfgang Sarlet e Tiago Fensterseifer - com vistas à formulação de horizontes normativos compatíveis com uma gestão ecologicamente correta e substancialmente democrática do Pantanal, - nos termos do que propõe Antônio Carlos Diegues - , calcada, sobretudo, na possibilidade de os povos e comunidades tradicionais participarem ativamente dos processos decisórios atinentes à gestão do Pantanal. 


\section{Pantanal Mato-grossense: sociobiodiversidade e conflitos socioambientais}

Em termos geofísicos, o Pantanal pode ser conceituado como parte do maior complexo de áreas úmidas ${ }^{2}$ do mundo ${ }^{3}$, formado pela interação das planícies de inundação de toda a malha hidrográfica da Bacia do Alto Paraguai ${ }^{4}$, localizado na parte central do continente sul-americano, abrangendo parcelas dos territórios do Brasil, Paraguai e Bolívia.

Corresponde a $2 \%$ de todo o território brasileiro a porção de terras abrangida pelo Pantanal5. Deste total, 65\% se encontram em território sul-mato-grossense, e os 35\% restantes em terras de Mato Grosso.

A respeito de sua constituição, Neto afirma que este bioma se configura como um ponto de encontro de ecossistemas característicos da América do Sul, como a floresta amazônica, os cerrados e savanas do Brasil central, havendo, inclusive, resquícios da vegetação de clima do passado semiárido ${ }^{6}$, daí resultando uma profusa biodiversidade:

[...] entre as espécies mais frequentes, que constituem referências para qualquer pantaneiro, o Pantanal recebeu da Amazônia o babaçu (Orbignya speciosa), da Floresta Atlântica, a piúva ou ipê roxo (Tabebuia avellaneda), do Cerrado, o carandá (Copernicia Alba), e da Caatinga, o mandacaru (Cereus jamacaru). Entre os [...], o maior felino da América do Sul, a onça pintada (Panthera jaguarius).?

\section{$[\ldots]$}

Tomando-se apenas os números mais prováveis, conhecem-se mais de 657 aves, das quais 463 são registradas para a planície pantaneira, 263

2 Conforme o Tratado de RAMSAR, celebrado em 1971, do qual o Brasil é signatário: "[...] zonas úmidas são áreas de pântano, charco, turfa ou água, natural ou artificial, permanente ou temporária, com água estagnada ou corrente, doce, salobra ou salgada, incluindo áreas de água marítima com menos de seis metros de profundidade na maré baixa". Disponível em: < http://www.mma.gov.br/images/arquivos/biodiversidade/ biodiversidade_aquatica/zonas_umidas/texto_convencao_ramsar.pdf > Acesso em: 20 jan. 2016.

3 SILVA, Carolina Joana; NUNES, José Ribeiro da Silva; SIMONI, Jane. O sistema de Baías Chacororé - Sinhá Mariana. In: SILVA, Carolina Joana da; SIMONI, Jane. (Org.). Agua, biodiversidade e cultura do Pantanal: estudos ecológicos e etnobiológicos no sistema de Baías Chacororé - Sinhá Mariana. Cáceres: Ed. UNEMAT, 2012. p. 28.

4 CALHEIROS, Débora Fernandes; OLIVEIRA, Márcia Divina de. O rio Paraguai e sua planície de inundação: o Pantanal Mato-grossense. In: Ciência e Ambiente, n. 41, p. 121, jul./dez. 2010.

5 Mapa de Cobertura Vegetal dos Biomas Brasileiros. Disponível em: < http://www.mma.gov.br/estruturas/

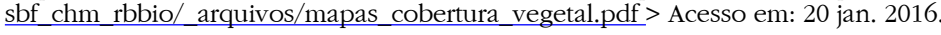

6 NETO, José Pereira de Queiroz. Pantanal, Pantanais: Patrimônio Nacional. In: RIBEIRO, Wagner Costa (Org.). Patrimônio Ambiental Brasileiro. São Paulo: Editora da Universidade de São Paulo: Imprensa Oficial, 2003. p. 283-301.

7 Idem, Ibidem. 
peixes, 113 répteis, dos quais 85 correspondem à planície pantaneira, e 132 mamíferos. $^{8}$

Mais do que abrigar biodiversidade, o Pantanal desempenha serviços ecológicos ${ }^{9}$ de importância regional e internacional, dos quais dependem vários países da América do Sul, já que se localiza numa bacia hidrográfica transfronteiriça. ${ }^{10}$

A par disso, ressalta-se a existência das sociedades tradicionais ${ }^{11}$ há muito presentes no Pantanal. Ribeirinhos, pescadores, quilombolas, indígenas etc.: é grande o número de comunidades, e variado o espectro étnico e cultural dos povos tradicionais habitantes dessa região, que é rica não só em patrimônio natural como também em manifestações culturais e saberes tradicionais, modos de ser, fazer e viver.

Umbilicalmente ligadas aos ciclos naturais, essas culturas aprenderam a viver nessa terra cientes da importância de sua conservação, pois sabem que são dependentes de seus recursos e fazem dessa ligação a fonte principal da construção de suas relações sociais e perpetuação de sua tessitura sociocultural.

Portanto, mais do que simples repositório de biodiversidade ou cenário de rara beleza cênica, esse bioma se configura num importante complexo

8 DOUROJEANNI, Marc J. Construindo o futuro do Pantanal. Rio de Janeiro: SESC, 2006. p. 31.

9 Conforme IRIGARAY, "são serviços ecológicos prestados pelas florestas tropicais os benefícios gerados pela cobertura florestal, não apenas em proveito humano, e incluem muito além do estoque de carbono nela armazenado, mas também a provisão de alimentos (para homens e animais) e os serviços de regulação do fluxo hídrico e do clima, reciclagem de nutrientes, geração de chuvas, absorção do dióxido de carbono, entre outros". IRIGARAY, Carlos Teodoro José Hugueney. Pagamento por serviços Ecológicos e o Emprego do REDD na Amazônia. In: LAVRATTI, Paula; PRESTES, Vanêsca Buzelado. (Org.). Direito e Mudanças Climáticas 3. Serviços Ecológicos. 1. ed. 2010. v. 1, p. 9-38. Apesar de referir-se especificamente às florestas tropicais, o conceito de serviços ecológicos acima expendido compreende os elementos essenciais de sua definição.

10 Dentre os diversos serviços ecológicos realizados pelo Pantanal — também por outros biomas — tais como sequestro de carbono, manutenção da biodiversidade, regulação termoclimática, etc., Silva destaca que o "Pantanal representa um imenso reservatório natural de vazões oriundas do Rio Paraguai e de seus afluentes, [...]. Essa condição de funcionar como um reservatório natural temporário, atrasar e atenuar as enchentes rio abaixo, confere ao Pantanal o mais importante atributo das suas funções ambientais, os serviços de regulação do sistema Paraguai”. SILVA, Carolina Joana; NUNES, José Ribeiro da Silva; SIMONI, Jane. O sistema de Baías Chacororé - Sinhá Mariana. In: SILVA, Carolina Joana da; SIMONI, Jane. (Org.). Água, biodiversidade e cultura do Pantanal: estudos ecológicos e etnobiológicos no sistema de Baías Chacororé - Sinhá Mariana. Cáceres: Ed. UNEMAT, 2012. p. 29.

11 De acordo com Diegues, pode-se entender como "sociedades tradicionais" os [...] grupos bumanos culturalmente diferenciados que bistoricamente reproduzem seu modo de vida, de forma mais ou menos isolada, com base em modos de cooperação social e formas específicas de relações com a natureza, caracterizados tradicionalmente pelo manejo sustentado do meio ambiente. Essa noção se refere tanto a povos indigenas quanto a segmentos da população nacional que desenvolveram modos particulares de existência, adaptados a nichos ecológicos específicos. DIEGUES. Antônio Carlos (Org.) Os saberes tradicionais e a Biodiversidade no Brasil. São Paulo: Ministério do Meio Ambiente, 2000, p. 22. Disponível em: < http://www.mma.gov.br/estruturas/chm/ arquivos/saberes.pdf >. Acesso em 14 Fev. 2016. 
de ecossistemas de cujo equilibrio dependem não só espécies de plantas ou animais, como também várias comunidades humanas.

Não é por outra razão que o Pantanal é contemplado por diversas normas jurídicas internacionais ${ }^{12}$, nacionais ${ }^{13}$ e estaduais ${ }^{14}$, que, no entanto, ainda carecem de efetividade prática, sobretudo no que concerne à proteção do pulso de inundação e sua interconexão com os planaltos adjacentes.

Pulso de inundação é o nome que se dá ao complexo processo natural responsável pelo alagamento periódico da planície pantaneira propriamente dita. Segundo Resende: ${ }^{15}$

[...] os processos biológicos e biogeoquímicos no sistema rio/planície de inundação são descritos pelo conceito do pulso de inundação, que considera as trocas laterais entre o rio e suas planícies de inundação bem como as trocas entre as fases terrestre (seca) e aquática (cheia) nessa mesma planície.

Para a manutenção deste mecanismo - essencialmente importante para o equilibrio da fauna e da flora pantaneiras, mas também para a digna existência das populações tradicionais - é fundamental a preservação dos rios cujas águas abastecem a planície, as chamadas water towers ${ }^{16}$, que nascem nos planaltos e chapadões vizinhos, em região de cerrado.

Daí é que resulta a visceral interdependência do Pantanal em relação à conservação dos chapadões circundantes, pois a proteção da planície alagável, por si só, não garantirá a preservação do bioma pantaneiro caso as nascentes dos rios que o formam continuem sendo destruídas.

Esta constatação, porém, evidentemente não tem sido levada em conta na elaboração e implementação de políticas públicas e ações de governo incidentes sobre este espaço, o mesmo podendo ser dito a respeito das normas atinentes ao Pantanal.

No que se refere ao quadro normativo ambiental relativo ao Pantanal Mato-grossense, Irigaray et al. ${ }^{17}$ afirmam que:

12 Dentre as quais, destacam-se o Tratado da Bacia do Prata, aprovado pelo Decreto-lei n. 682/1969, e a Convenção de Ramsar, celebrada em 1971.

13 As mais importantes: Lei n. 6.938/81; Lei n. 9.605/98; Lei n. 12.651/2012.

14 Tanto a Constituição do Estado de Mato Grosso como a do Estado de Mato Grosso do Sul contêm dispositivos que tratam especificamente do Pantanal. Além disso, em 2008 foi aprovada a Lei Estadual n. 8.830/2008, que disciplina o uso e preservação da parcela deste bioma que se encontra em Mato Grosso.

15 RESENDE, Emiko Kawakami de. Pulso de inundação: processo ecológico essencial à vida do Pantanal. Corumbá: Embrapa Pantanal, 2008. p. 9.

16 The Nature Conservancy; WWF-Brasil. Análise de risco ecológico na Bacia do Rio Paraguai-Argentina, Bolivia, Brasil e Paraguai. 1. ed. Bras1lia: 2012. p. 38.

17 IRIGARAY, C. T. H.; DA SILVA, Carolina Joana; MEDEIROS, Heitor Queiroz; GIRARD, Pierre; FAVA, Gustavo 
No seu estado atual, o marco regulatório ambiental existente no Brasil não pode garantir a manutenção do pulso de inundação que é vital para a sobrevivência do Pantanal. Ademais não há nenhuma lei federal que estabeleça os princípios de gestão e proteção desse Patrimônio Nacional, ou que faça sequer referência ao pulso de inundação do Pantanal Mato-Grossense. Assim também a lei do Estado de Mato Grosso sobre a gestão e proteção da Bacia do Alto Paraguai deixa de regular as relações entre a planície do Pantanal e planaltos adjacentes, onde esse pulso de inundação é gerado. ${ }^{18}$

Como se vê, a despeito do tratamento especial dispensado pela Constituição Federal, que o elevou ao status de Patrimônio Nacional (art. 225, $\S 4^{\circ}$, da CF), a preservação do Pantanal não parece constar da lista de prioridades dos governos federal e estaduais, daí resultando um grave cenário, propício à eclosão de conflitos socioambientais.

Esta conjuntura tornou-se ainda mais preocupante com a entrada em vigor do Novo Código Florestal.

\section{Os impactos do Novo Código Florestal sobre o Pantanal}

Instituído pela Lei n. 12.651/2012, o Novo Código Florestal, dentre outras disposições, estabelece as normas gerais sobre a proteção da vegetação no âmbito do território brasileiro.

Embora no art. $1^{\circ}$, parágrafo único, o legislador tenha consignado que esta lei objetiva o desenvolvimento sustentável, Purvim Figueiredo ${ }^{19}$ afirma que sua promulgação:

[...] representou, insofismavelmente, uma vitória da bancada ruralista representante da classe que há cinco séculos comanda os destinos de nosso país. Trata-se do mais grave retrocesso político e jurídico para a cidadania ambiental.

Inúmeros foram os reveses socioambientais operados pelo Novo Código

Crestani; MACIEL, J. C.; GALLO, Rogério Luis; NOVAIS, Lafayette Garcia. O Pantanal Matogrossense enquanto patrimônio nacional no contexto das mudanças climáticas. In: SILVA, Solange; CUREAU, Sandra; LEUZINGER, Márcia. (Org.). Mudança do Clima. Desafios jurídicos, econômicos e socioambientais. 1. ed. São Paulo: Fiuza, 2011. p. 82.

18 Idem, Ibidem.

19 PURVIM FIGUEIREDO, Guilherme José. Capítulo 1. Art. 1. In: MILARÉ, Édis; LEME MACHADO, Paulo Afonso (Coord.). Novo código florestal: comentários à Lei 12.651, de 25 de maio de 2012, à Lei 12.727, de 17 de outubro de 2012 e do Decreto 7.830, de 17 de outubro de 2012. 2. ed. São Paulo: RT, 2013. p. 33. 
Florestal, dentre os quais talvez o mais danoso seja a alteração nos critérios para o estabelecimento das áreas de preservação permanente, as APPs. ${ }^{20}$

De acordo com o "antigo" Código Florestal, Lei n. 4.771/65, modificada pela Lei n. 7.803/89, as APPs lindeiras aos cursos d'água definiam-se a partir do nível mais alto destes cursos:

Art. $2^{\circ}$ Consideram-se de preservação permanente, pelo só efeito desta Lei, as florestas e demais formas de vegetação natural situadas:

\section{$[\ldots]$}

a) ao longo dos rios ou de qualquer curso d'água desde o seu nível mais alto em faixa marginal cuja largura mínima será: (sem destaques no original).

Já nos termos do novo Código Florestal:

Art. $4^{\circ}$ Considera-se Área de Preservação Permanente, em zonas rurais ou urbanas, para os efeitos desta Lei:

I - as faixas marginais de qualquer curso d'água natural perene e intermitente, excluídos os efêmeros, desde a borda da calha do leito regular, em largura mínima de: (sem destaques no original).

De acordo com o código revogado, praticamente toda a planície alagável da Bacia do Alto Paraguai poderia ser considerada uma APP, uma vez que durante a estação das cheias a maior parte desta região fica submersa, sendo este o critério definidor para que fossem estabelecidas as APPs aí localizadas. Muito embora este não fosse o entendimento jurídico predominante acerca da incidência deste dispositivo sobre o Pantanal, o texto legal então vigente permitia a evolução da compreensão dos intérpretes, daí podendo decorrer consequências jurídicas decisivas para a conservação do Pantanal.

Contudo, ao estipular que a definição das APPs passa a contar a partir da borda da calha do leito regular dos cursos d'água, o legislador federal positivou um cenário jurídico-ambiental agudamente danoso ao Pantanal. A propósito, para os efeitos desta lei entende-se por leito regular "a calha por onde correm regularmente as águas do curso d'água durante o ano". ${ }^{21},{ }^{22}$

20 Com a mesma redação do antigo Código Florestal, modificado pela Medida Provisória nº 2.166-67/2001, o art. $3^{\circ}$, inc. II, da Lei n. 12.651/2012, determinou que, para os efeitos desta Lei, considera-se área de preservação permanente a área protegida, coberta ou não por vegetação nativa, com a função ambiental de preservar os recursos hídricos, a paisagem, a estabilidade geológica e a biodiversidade, facilitar o fluxo gênico de fauna e flora, proteger o solo e assegurar o bem-estar das populações humanas.

21 Art. $3^{\circ}$, inc. XIX, da Lei n. 12.651/2012.

22 Ressalta-se que esta definição guarda estrita correspondência com a que foi utilizada na Convenção de Ramsar 
Ora, em vista da dinâmica ínsita ao pulso de inundação dessa planície, o novo critério definidor das APPs é insuficiente para proteger o Pantanal, porquanto a natureza cíclica do seu regime hidrológico faz com que mesmo durante a estação seca as áreas não consideradas APPs desempenhem uma função ambiental fundamental para a manutenção do equilibrio ecológico regional.

A este respeito, Piedade et al..$^{23}$ pontuam que:

Em ecossistemas de pulso, como o Pantanal, a referência à largura da calha regular não aborda o mais importante dos aspectos nesses sistemas, que é a extensão e expansão lateral dessas áreas úmidas, que varia ao longo da paisagem e do ano. Por exemplo, na entrada da planície Pantaneira, a área úmida do Rio Cuiabá é estreita, mas dentro da planície é muito larga, apesar de o leito regular ter a mesma largura. Desta forma, é evidente que a proteção eficiente das áreas só é possível usando o nível máximo de inundação como ponto de referência.

Destarte, parece-nos que a definição legal de leito regular estabelecida pelo legislador não se compatibiliza com a definição de áreas úmidas contida no inc. XXV do art. $3^{\circ}$ do Novo Código Florestal:

Art. $3^{\circ}$ Para os efeitos desta Lei, entende-se por:

$$
[\ldots]
$$

XXV - áreas úmidas: pantanais e superfícies terrestres cobertas de forma periódica por águas, cobertas originalmente por florestas ou outras formas de vegetação adaptadas à inundação.

Com efeito, este dispositivo aponta expressamente que as áreas úmidas se caracterizam pelas inundações periódicas, de sorte que a vegetação aí compreendida é adaptada a estes ciclos. E mais, embora não tenha sido mencionado pelo legislador, tem-se que não só a vegetação, mas também a fauna é adaptada e umbilicalmente dependente da dinâmica das águas pantaneiras.

para o estabelecimento de Zonas Úmidas. AYALA, Patryck de Araújo. Capítulo 3. Art. 10. In: MILARÉ, Édis; LEME MACHADO, Paulo Afonso (Coord.) Novo código florestal: comentários à Lei 12.651, de 25 de maio de 2012, à Lei 12.727, de 17 de outubro de 2012 e do Decreto 7.830, de 17 de outubro de 2012. 2. ed. São Paulo: RT, 2013. p. 189.

23 PIEDADE, Maria Teresa; JUNK, Wolfgang J.; SOUZA JR, Paulo Teixeira; DA CUNHA, Catia Nunes; SCHÖNGART, Jochen; WITTMAN, Florian; GIRARD, Pierre. As áreas úmidas no âmbito do Código Florestal brasileiro. In: LIMA, André et al (Coords.). Código Florestal e a ciência: o que nossos legisladores ainda precisam saber. Sumários executivos de estudos científicos sobre impactos do Projeto do Código Florestal. Brasilia: Comitê Brasil em defesa das florestas e do desenvolvimento sustentável, 2012. p. 13. 
Logo, é razoável a afirmativa de que se trata, em verdade, de um bioma cujas peculiaridades ecológicas exigem critérios diferenciados para a determinação de APPs.

A questão da demarcação e definição do leito do rio é sem dúvida o ponto mais polêmico no que diz respeito às áreas úmidas brasileiras no bojo do Código Florestal. Como as faixas marginais aos rios e de outras tipologias de áreas úmidas são, por definição, categorizadas como APPs, da definição inadequada de leito do rio derivam os problemas para a demarcação das APPs. Estas também devem ser delimitadas a partir do nível mais alto da cheia nas áreas úmidas do território nacional, sendo preservados os direitos de uso das populações tradicionais de ribeirinhos e indígenas que as habitam e utilizam milenarmente. ${ }^{24}$

Assim, também a população de modo geral e especialmente as comunidades tradicionais e etnias indígenas localizadas no Pantanal dependem primordialmente do equilibrado funcionamento do pulso de inundação que distingue este bioma. Muito além de influenciar diretamente seu sustento material (caça, pesca, cultivo de lavouras, criação de rebanhos, etc.), o ciclo das águas representa um dos pontos fundamentais dos modos de ser, fazer e viver dos habitantes da região, organizando a tessitura sociocultural destas comunidades e etnias.

Logo, ao permitir a exploração de áreas que no antigo regime jurídico integravam as APPs, o Novo Código Florestal representou, mormente no contexto do bioma pantaneiro, uma involução em termos de legislação ambiental com indesejáveis repercussões na proteção do patrimônio natural e cultural brasileiro, ou seja, uma medida legislativa socioambientalmente retrógrada, em total desalinho com os preceitos constitucionais, sobretudo os artigos 216, 225 e 231 da CF88.

Logo, uma interpretação simplória e gramatical dos dispositivos legais contidos no Novo Código Florestal permitiria a afirmação de que as faixas de terra da grande planície inundável da Bacia do Alto Paraguai não abrangidas por APPs poderiam ser exploradas, mesmo se tratando de espaços primordialmente importantes para a manutenção do equilibrio socioambiental da região.

Isto nos remete à previsão inscrita no art. $10^{25}$ da Lei n. 12.651/2012:

24 Idem, Ibidem.

25 Este artigo, juntamente com o artigo 11, insere-se no Capítulo III, intitulado "Das Áreas de Uso Restrito". 
Art. 10. Nos pantanais e planícies pantaneiras, é permitida a exploração ecologicamente sustentável, devendo-se considerar as recomendações técnicas dos órgãos oficiais de pesquisa, ficando novas supressões de vegetação nativa para uso alternativo do solo condicionadas à autorização do órgão estadual do meio ambiente, com base nas recomendações mencionadas neste artigo.

Ora, este dispositivo estabelece a possibilidade de utilização das áreas exceto as APPs - localizadas nos pantanais e planícies pantaneiras, desde que autorizada por órgão estadual do meio ambiente, e desde que se trate de atividade ecologicamente sustentável praticada de acordo com as recomendações técnicas dos órgãos oficiais de pesquisa.

Em virtude da modificação da regra que estabelecia os critérios para a definição das APPs, áreas onde se proibia a supressão vegetal passaram a poder ser destinadas ao uso alternativo do solo, desde que atendidos os critérios arrolados do aludido art. 10.

Todavia, Ayala ${ }^{26}$ afirma que:

Em razão da dinâmica das relações bióticas nos ecossistemas que compõem o pantanal mato-grossense dependerem fortemente do regime de cheias e secas, a alteração realizada sobre o texto do art. $3^{\circ}, \mathrm{XXV}$, comprometeu severamente a capacidade de se proteger adequadamente os processos ecológicos que viabilizam a vida no bioma, sendo insuficiente, nesse sentido, que o texto do art. 10 condicione as atividades econômicas à alternativa de sustentabilidade proposta pelo órgão ambiental estatal.

Consoante este raciocínio, o simples fato de as APPs passarem a ser definidas a partir da calha do leito regular dos cursos d'água torna insuficiente, em termos de proteção ambiental, que as atividades realizadas no Pantanal sejam praticadas de modo sustentável, mesmo se de acordo com as recomendações técnicas elaboradas pelos órgãos oficiais de pesquisa.

Assim, não bastasse a já deficiente regulamentação pretérita, a entrada em vigor do Novo Código Florestal significou um retrocesso na proteção ambiental do Pantanal.

Portanto, embora o Pantanal Mato-grossense seja contemplado direta e

Trata-se de uma categoria autônoma de áreas protegidas, cuja definição legal, segundo AYALA, Patryck de Araújo, consta do já citado inc. XXV do art. $3^{\circ}$ da Lei n. 12.651/2012.

26 PIEDADE et al., op. cit., p. 13. 
indiretamente por um amplo e variado quadro normativo (internacional, federal e estadual), este bioma ainda carece de uma regulação mais efetiva, que leve em conta suas peculiaridades hidro-ecológicas - designadamente o pulso de inundação e sua visceral relação com os planaltos e chapadões circunvizinhos - , sem desconsiderar o fecundo espectro sociocultural das comunidades tradicionais e povos indígenas que aí habitam, e que fazem deste um espaço de singularíssima sociobiodiversidade.

Todavia, conquanto o cenário legal examinado esteja em flagrante descompasso com o que fora estabelecido pelo legislador constituinte originário, a nosso ver não se pode afirmar que inexistem, por completo, quaisquer dispositivos jurídicos aptos à formulação de interpretações tendentes à promoção da conservação e sustentabilidade deste bioma, vez que o texto legal, ao permitir interpretações variadas, configura um âmbito de disputa sociopolítica.

\section{O Marco Jurídico-constitucional Socioambiental}

A lei mais importante do ordenamento jurídico brasileiro é a Constituição Federal de 1988 e, como tal, impõe-se como bússola interpretativa e critério definitivo para as atividades legislativa, administrativa e jurisdicional levadas a efeito por cada um dos respectivos agentes públicos das três esferas federativas.

Ferraz $\mathrm{Jr}^{27}$ pontua que:

Entende-se usualmente por Constituição a lei fundamental de um país, que contém normas respeitantes à organização básica do Estado, ao reconhecimento e à garantia dos direitos fundamentais do ser humano e do cidadão, as formas, limites e competências do exercício do Poder Público (legislar, julgar, governar).

Mais do que um rol de comandos normativos, a Constituição representa um documento jurídico-político em que se inscrevem as normas fundamentais e estruturantes de uma comunidade sociopolítica.

Levando em conta os pressupostos e desdobramentos políticos e sociais de uma Lei Fundamental, Afonso da Silva ${ }^{28}$ afirma que o entendimento jurídico

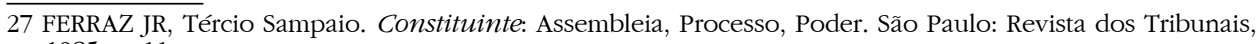
1985. p. 11.

28 AFONSO DA SILVA, José. Curso de Direito Constitucional Positivo. 16. ed. Brasil, 1999. 
acerca da Constituição deve considerar "o seu aspecto normativo, não como norma pura, mas como norma em sua conexão com a realidade social, que lhe dá o conteúdo fático e o sentido axiológico". ${ }^{29}$

Assim, quando da elaboração do texto constitucional de 1988, o clamor popular e a articulação de alguns setores da sociedade fizeram com que determinados valores constassem explicitamente do texto promulgado.

A chamada Constituição Cidadã, portanto, trouxe em seu bojo um conjunto de princípios e normas que na época de sua elaboração representava os objetivos e aspirações da sociedade brasileira.

Ao lado da igualdade, liberdade, justiça social, livre iniciativa, etc., sobressai a proteção do meio ambiente como direito fundamental cuja consecução incumbe ao Estado e a toda coletividade. Trata-se, assim, de um direito-dever fundamental, cuja positivação corresponde, em certa medida, à tomada de consciência da crise ambiental.

Assim, de acordo com Sarlet e Fensterseifer: ${ }^{30}$

Se considerarmos os novos valores impulsionados pelas relações sociais contemporâneas, especialmente a partir da década de 1970, tem-se hoje a presença marcante da defesa ecológica e da melhoria da qualidade de vida, como decorrência da atual crise ambiental. Assim como outrora a Teoria da Constituição e o Direito Constitucional estiveram comprometidos com a afirmação, na ordem da evolução, dos valores liberais e sociais (valores que, embora em contexto e com sentido revisto e reconstruído, seguem incorporados à agenda constitucional), hoje a proteção e promoção do ambiente desponta como novo valor constitucional.

Profundamente ligada à ideia de proteção do meio ambiente desabrocha a noção de sustentabilidade, também acolhida e positivada pelo constituinte de 1988. A propósito da sustentabilidade, na qualidade de princípio jurídico, Freitas afirma que:

[...] trata-se do princípio constitucional que determina, com eficácia direta e imediata, a responsabilidade do Estado e da sociedade pela concretização solidária do desenvolvimento material e imaterial, socialmente inclusivo, durável e equânime, ambientalmente limpo; inovador, éticos e eficientes, no intuito de assegurar, preferencial-

\footnotetext{
29 Idem, Ibidem, p. 41.

30 SARLET, Ingo Wolfgang; FENSTERFEIFER, Tiago. Direito Constitucional Ambiental: Constituição, Direitos Fundamentais e Proteção do Meio Ambiente. 3. ed. São Paulo: Editora Revista dos Tribunais, 2013. p. 29.
} 
mente de modo preventivo e precavido, no presente e no futuro, o direito ao bem-estar ${ }^{31}$.

No entanto, para além de uma visão estritamente ecológica, o direito ao meio ambiente constitucionalmente consagrado pressupõe uma dimensão sociocultural intimamente atrelada à ideia de equilibrio socioambiental.

Ou seja, o objetivo de se proporcionar a proteção dos bens naturais com vistas à garantia de um meio ambiente sadio e ecologicamente equilibrado não pode nem deve prescindir dos direitos políticos, culturais, econômicos e sociais também constitucionalmente garantidos a todos os cidadãos brasileiros.

Eis o que Sarlet e Fensterseifer ${ }^{32}$ denominam "marco jurídico-constitucional socioambiental". Em suas palavras:

A adoção do marco jurídico-constitucional socioambiental resulta [...] da convergência necessária da tutela dos direitos sociais e dos direitos ambientais num mesmo projeto jurídico-político para o desenvolvimento humano em padrões sustentáveis, inclusive pela perspectiva da noção ampliada e integrada dos direitos econômicos, sociais, culturais e ambientais. $^{33}$

Isto é, a proteção do meio ambiente deve andar pari passu com a concretização dos demais direitos e garantias fundamentais, uma vez que a necessidade de se assegurar a manutenção do equilibrio ecológico dos ecossistemas não pode menoscabar a implementação dos chamados direitos fundamentais de $1^{\underline{a}}$ e $2^{\underline{a}}$ dimensão: direitos civis, políticos, sociais, econômicos e culturais.

Além disso, a própria noção de meio ambiente constitucionalmente positivada transpassa o viés materialista insculpido na lei que instituiu a Política Nacional do Meio Ambiente, a Lei n. 6.938/81.

Nos termos deste diploma, meio ambiente constitui "o conjunto de condições, leis, influências e interações de ordem física, química e biológica, que permite, abriga e rege a vida em todas as suas formas". ${ }^{34}$

Não obstante esta lei ter sido recepcionada pela vigente ordem constitucional, se pode dizer que a noção de meio ambiente evoluiu, porquanto

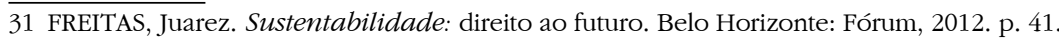

32 SARLET, Ingo Wolfgang; FENSTERFEIFER, Tiago. Estado socioambiental e mínimo existencial (ecológico?): algumas aproximações. In: SARLET, Ingo Wolfgang (Org.). Estado Socioambiental e Direitos Fundamentais.

Porto Alegre: Livraria do advogado Editora, 2010.

33 Idem, Ibidem, p.13.

34 Conceito constante do art. $3^{\circ}$, inc. I, da Lei n. 6.938/81. 
o legislador constituinte, atento à marcha da história e aos conflitos sociais, atrelou a este conceito as dimensões sociais, políticas e culturais inerentes às relações homem-meio ambiente.

Diante disso, com base no que a doutrina denomina de Princípio Hermenêutico da Máxima Efetividade das Normas Constitucionais ${ }^{35}$, Santilli36 aduz que:

O texto constitucional revela a compreensão de que não basta proteger a biodiversidade: a diversidade de espécies, genética e de ecossistemas, sem assegurar a diversidade cultural que está intimamente relacionada a esta. A síntese socioambiental está presente na interface entre biodiversidade e sociodiversidade, permeada pelo multiculturalismo, pela plurietnicidade e pelo enfoque humanista. Só se dará plena eficácia e efetividade às normas constitucionais se forem compreendidas em toda a sua essência, se pudermos retirar o máximo delas. Interpretar as normas constitucionais de conteúdo socioambiental apenas pelo viés da tutela ao patrimônio natural deixa a sua efetividade muito aquém do desejado e da solução hermenêutica que melhor atende ao princípio da máxima efetividade.

Nessa linha, portanto, há que se articular sistêmica e finalisticamente as disposições inscritas nos artigos 216, 225 e 231 da Constituição Federal, com o fito de promover a proteção integrada dos elementos naturais e culturais que compõem o patrimônio socioambiental brasileiro.

Nessa contextura, dentre os deveres constitucionalmente atribuídos ao poder público, sobressai o mister de preservar os processos ecológicos essenciais (art. 225, § $1^{\circ}$, inc. I, da CF88), cuja aplicação, no caso do Pantanal, significa principalmente garantir a integridade do pulso de inundação e da planície alagável. A isto, por conseguinte, se articula o dever de assegurar a proteção e perpetuação das culturas e povos tradicionais associados a este bioma (art. 216, inc. II c/c art. 231, § $1^{\circ}$, ambos da CF88).

Sendo assim, deveras razoável a afirmação de que a síntese socioambiental

35 "Este Princípio, também designado por princípio da eficiência ou princípio da interpretação efectiva, pode ser formulado da seguinte maneira: a uma norma constitucional deve ser atribuído o sentido que maior eficácia lhe dê. É um princípio operativo em relação a todas e quaisquer normas constitucionais, e embora a sua origem esteja ligada à tese da actualidade das normas programáticas (Thoma), é hoje sobretudo invocado no âmbito dos direitos fundamentais (no caso de dúvidas deve preferir-se a interpretação que reconheça maior eficácia aos direitos fundamentais)". In: GOMES CANOTILHO, José Joaquim. Direito constitucional e teoria da Constituição. 3. ed. Coimbra: Livraria Almedina, 1998. p. 1149.

36 SANTILLI, Juliana. Socioambientalismo e novos direitos: proteção jurídica à diversidade biológica e cultural. São Paulo: Editora Peirópolis, 2005. p. 59. 
inscrita no texto constitucional abrange a noção de cidadania indígena ativa, conforme propõe Dantas: ${ }^{37}$

[...] o reconhecimento constitucional dos índios, e suas organizações sociais de modo relacionado, configuram, no âmbito do direito, um novo sujeito indígena, diferenciado, contextualizado, concreto, coletivo, ou seja, sujeito em relação com suas múltiplas realidades socioculturais, o que permite expressar a igualdade a partir da diferença. O marco legal desse reconhecimento, em razão da dificuldade de espelhar exaustivamente a grandiosa complexidade e diversidade que as sociedades indígenas representam, está aberto para a confluência das diferentes e permanentemente atualizadas maneiras indígenas de conceber a vida com seus costumes, línguas, crenças e tradições, aliadas sempre ao domínio coletivo de um espaço territorial.

Logo, a articulação da noção de cidadania indígena ${ }^{38}$ ativa com a síntese socioambiental resulta num arranjo jurídico-constitucional com base no qual se pode afirmar que mesmo diante de textos normativos cujas redações veiculam, em princípio, comandos legais socioambientalmente inadequados, há que prevalecer as linhas interpretativas tendentes à proteção dos bens ambientais em harmonia com os demais direitos fundamentais, uma vez que a perspectiva socioambiental adotada pelo constituinte deve orientar e fundamentar toda a legislação infraconstitucional brasileira, conferindo-lhe coerência e unidade axiológico-normativa. ${ }^{39}$

A partir disto é que se pode concluir que o quadro normativo direta ou indiretamente incidente sobre o Pantanal Mato-grossense, embora marcado pela vagueza e inadequação socioambiental, permite a consecução de caminhos hermenêuticos propícios à implementação de políticas públicas sustentáveis, que além de promoverem a conservação dos recursos naturais, oportunizem às comunidades tradicionais e povos indígenas a participação nos processos decisórios e a manutenção das condições necessárias à produção e reprodução de seus costumes e modos de ser, fazer e viver.

37 DANTAS, Fernando Antonio de Carvalho. Os povos indígenas brasileiros e a "Cidadania Ativa". Revista Argumenta Journal Law, Jacarezinho - PR, n. 5, p. 180-194, fev. 2013. Disponível em: < http://seer.uenp. edu.br/index.php/argumenta/article/view/46 > Acesso em: 10 abr. 2016.

38 Em consonância com a noção de cidadania ativa, a Convenção n. 169 da Organização Internacional do Trabalho - OIT, da qual o Brasil é signatário desde de 2002, nos termos do Decreto Legislativo n. 143/2002. Cf., em especial, os artigos 6, 7, 13, 14 e 15.

39 SANTILLI. Op. Cit., p. 60. 


\section{5. $O$ art. 10 da Lei n. 12.65 1/2012 à luz do Marco Jurídico- constitucional Socioambiental}

Conquanto o Novo Código Florestal - ao modificar os critérios de definição das APPs - tenha representado, por um lado, um retrocesso em termos de proteção ambiental, por outro, é possível que o art. 10 desta lei ofereça possibilidades viáveis para a consecução de uma gestão socioambientalmente sustentável do Pantanal.

Com efeito, a redação do art. 10 da Lei n. 12.651/2012 levanta uma série de relevantes questões acerca do modo como se dará sua aplicação. Primeiramente cabe questionar sobre o que se pode entender por "exploração ecologicamente sustentável". Em segundo lugar é pertinente a indagação a respeito do processo de elaboração das "recomendações técnicas" com base nas quais poderá ser desenvolvido o uso alternativo do solo.

Pois bem, uma primeira aproximação leva-nos a crer que o termo "exploração ecologicamente sustentável" significa que tão somente os elementos naturais são levados em conta na estipulação dos critérios de exploração dos espaços referidos no art. 10. Nessa perspectiva estritamente "naturalista", por assim dizer, pouco ou nada importam os fatores culturais e sociais concernentes aos povos e comunidades tradicionais localizados no Pantanal e diretamente ligados à sua sustentabilidade.

Nessa linha interpretativa, uma determinada atividade econômica que se instalasse neste bioma e explorasse seus recursos naturais sem causar significativos impactos ambientais - de modo a não pôr em risco a sustentabilidade ecológica da região - poderia ser perfeitamente considerada como legalmente escorreita, mesmo que alguma etnia indígena e/ou comunidade tradicional fosse mais ou menos afetada, tanto em termos socioculturais como no que tange à sua subsistência material.

Entretanto, em vista da síntese socioambiental consagrada na Constituição Federal de 1988, é inadequada a perspectiva hermenêutica que enxerga o meio ambiente desatrelado dos demais direitos fundamentais, sobretudo no que tange aos componentes socioculturais direta e indiretamente associados.

Logo, tanto a cultura dos povos e comunidades tradicionais deve ser compreendida em sua relação com o meio ambiente, quanto este deve ser concebido como elemento visceral daquela, de modo a formarem um complexo bem socioambiental. 
A respeito, Marés ${ }^{40}$ aduz que:

Os bens socioambientais são todos aqueles que adquirem essencialidade para a manutenção da vida de todas as espécies (biodiversidade) e de todas as culturas humanas (sociodiversidade). Assim, os bens ambientais podem ser naturais ou culturais, ou se melhor podemos dizer, a razão da preservação há de ser predominantemente natural ou cultural se tem como finalidade a bio ou a sociodiversidade, ou a ambos, numa interação necessária entre o ser humano e o ambiente em que vive.

Desse modo, embora a redação do art. 10 a princípio aponte para uma interpretação reducionista do meio ambiente, os desdobramentos jurídicos resultantes deste comando legal devem necessariamente se pautar por uma concepção que integre cultura e meio ambiente, em consonância com os preceitos socioambientais irradiados pelo texto constitucional.

Assim, é juridicamente inadequada e socioambientalmente ineficaz a opção hermenêutica que desmereça a interdependência entre a conservação do equilibrio ecológico e as culturas tradicionais associadas.

Destarte, há que se buscar uma via interpretativa capaz de aliar a conservação do equilibrio ecológico aos demais fatores que compõem a ideia de sustentabilidade, mormente no que atine aos direitos socioculturais dos povos e comunidades tradicionais.

Ora, não é outro o entendimento do legislador federal, que por meio do Decreto n. 6.040/2007 instituiu a Politica Nacional de Desenvolvimento Sustentável dos Povos e Comunidades Tradicionais. De acordo com este diploma legal entende-se por:

I - Povos e Comunidades Tradicionais: grupos culturalmente diferenciados e que se reconhecem como tais, que possuem formas próprias de organização social, que ocupam e usam territórios e recursos naturais como condição para sua reprodução cultural, social, religiosa, ancestral e econômica, utilizando conhecimentos, inovações e práticas gerados e transmitidos pela tradição;

II - Territórios Tradicionais: os espaços necessários à reprodução cultural, social e econômica dos povos e comunidades tradicionais, sejam eles utilizados de forma permanente ou temporária, observado, no que

40 MARÉS DE SOUZA FILHO, Carlos Frederico. Introdução ao direito socioambiental. In: LIMA, André (Org.). O direito para o Brasil socioambiental. São Paulo: Instituto Socioambiental; Porto Alegre: Sérgio Antônio Fabris, 2002. p. 38. 
diz respeito aos povos indígenas e quilombolas, respectivamente, o que dispõem os arts. 231 da Constituição e 68 do Ato das Disposições Constitucionais Transitórias e demais regulamentações. ${ }^{41}$

Ou seja, as concepções de "Territórios" e "Povos e Comunidades Tradicionais" legalmente estabelecidas pressupõem a garantia de uma proteção especifica e integrada. Logo, não basta que se assegure o equilibrio ecológico do Pantanal em detrimento dos direitos fundamentais dos povos e comunidades tradicionais aí existentes, especialmente no que tange ao direito à ocupação dos espaços necessários à produção e reprodução de seus modos de ser, fazer e viver.

Aliás, pesquisas recentes têm apontado que o manejo ambiental praticado por estas sociedades contribui significativamente para a manutenção e até mesmo expansão da biodiversidade, uma vez que esta “[...] não é simplesmente um produto da natureza, mas em muitos casos é produto da ação das sociedades e culturas humanas, em particular, das sociedades tradicionais não industriais". ${ }^{42}$

Outrossim, Diegues ${ }^{43}$ afirma que a utilização de manejos ecologicamente sustentáveis é um dos traços característicos das comunidades e povos tradicionais: Um aspecto relevante na definição dessas culturas tradicionais é a existência de sistema de manejo dos recursos naturais marcados pelo respeito aos ciclos naturais, e pela sua exploração dentro da capacidade de

41 Eis a redação do art. 231 da Constituição Federal:

Art. 231. São reconhecidos aos índios sua organização social, costumes, línguas, crenças e tradições, e os direitos originários sobre as terras que tradicionalmente ocupam, competindo à União demarcá-las, proteger e fazer respeitar todos os seus bens.

$\S 1^{\circ}$ São terras tradicionalmente ocupadas pelos índios as por eles habitadas em caráter permanente, as utilizadas para suas atividades produtivas, as imprescindíveis à preservação dos recursos ambientais necessários a seu bem-estar e as necessárias a sua reprodução física e cultural, segundo seus usos, costumes e tradições. $\S 2^{\circ}$ As terras tradicionalmente ocupadas pelos índios destinam-se a sua posse permanente, cabendo-lhes o usufruto exclusivo das riquezas do solo, dos rios e dos lagos nelas existentes.

$\S 3^{\circ} \mathrm{O}$ aproveitamento dos recursos hídricos, incluídos os potenciais energéticos, a pesquisa e a lavra das riquezas minerais em terras indígenas só podem ser efetivados com autorização do Congresso Nacional, ouvidas as comunidades afetadas, ficando-lhes assegurada participação nos resultados da lavra, na forma da lei.

$\S 4^{\circ}$ As terras de que trata este artigo são inalienáveis e indisponíveis, e os direitos sobre elas, imprescritíveis. $\S 5^{\circ}$ É vedada a remoção dos grupos indígenas de suas terras, salvo, "ad referendum" do Congresso Nacional, em caso de catástrofe ou epidemia que ponha em risco sua população, ou no interesse da soberania do País, após deliberação do Congresso Nacional, garantido, em qualquer hipótese, o retorno imediato logo que cesse o risco.

$\S 6^{\circ}$ São nulos e extintos, não produzindo efeitos jurídicos, os atos que tenham por objeto a ocupação, o domínio e a posse das terras a que se refere este artigo, ou a exploração das riquezas naturais do solo, dos rios e dos lagos nelas existentes, ressalvado relevante interesse público da União, segundo o que dispuser lei complementar, não gerando a nulidade e a extinção direito a indenização ou a ações contra a União, salvo, na forma da lei, quanto às benfeitorias derivadas da ocupação de boa-fé.

$\S 7^{\circ}$ Não se aplica às terras indígenas o disposto no art. $174, \S 3^{\circ}$ e $\S 4^{\circ}$.

E, por sua vez, o art. 68 do ADCT:

Art. 68. Aos remanescentes das comunidades dos quilombos que estejam ocupando suas terras é reconhecida a propriedade definitiva, devendo o Estado emitir-lhes os títulos respectivos.

42 DIEGUES, Antônio Carlos; ARRUDA, Rinaldo S.V. (Org.). Saberes tradicionais e biodiversidade no Brasil. Brasilia: Ministério do Meio Ambiente; São Paulo: USP, 2001. p. 03.

43 Idem, Ibidem. 
recuperação das espécies de animais e plantas utilizadas. Esses sistemas tradicionais de manejo não são somente formas de exploração econômica dos recursos naturais, mas revelam a existência de um complexo de conhecimentos adquiridos pela tradição herdada dos mais velhos, por intermédio de mitos e símbolos que levam à manutenção e ao uso sustentado dos ecossistemas naturais.

Exemplo expressivo disto é a trama simbólico-cultural que envolve e orienta as práticas realizadas pelos índios Kura Bakairi, que habitam o centro-oeste brasileiro. Irigaray ${ }^{44}$ aponta que uma antiga estória deste povo conta que:

$\mathrm{Na}$ aldeia era costume de um casal tomar banho no rio todos os dias. Ao chegar na beira do rio os dois ficavam brincando, assim passavam o tempo. Um certo dia, chegando na beira do rio o marido jogou uns pingos d'água em sua mulher e puxou-a para dentro do rio, ela deu um mergulho, depois deu um mergulho longo e custou a aparecer; quando emergiu, já no meio do rio, tornou a mergulhar, dessa vez bem mais longe, quando apareceu, já se parecia com um jaú, com barba e tudo. O marido, desesperado, gritou: - Mulher, mulher, volte pra cá! E ela não respondia, mergulhou nas profundezas do rio e não apareceu mais. O marido, com muita tristeza, voltou para casa e contou à sua sogra que sua mulher desaparecera nas profundezas do rio. Enquanto isso, no fundo do rio, a mulher que virou jaú vivia feliz em sua nova morada, com o jaú que a raptara. Com o passar do tempo, a mulher que virou jaú teve vontade de voltar à casa de seus pais, para contar como se vivia dentro de um rio. Segundo narrou, lá ela viu que o rio não é apenas um rio, é a morada dos peixes, dos espíritos sobrenaturais, que devem ser tratados com muito respeito. Cada peixe tinha e tem função específica, por exemplo, os pequenos lambaris são coberturas de casas, a matrinxã é a mistura vermelha usada para fazer comida, o peixe-cachorro serve como espremedor de massa (tipiti) de mandioca, e a arraia serve como panela de barro. Ao ouvir a narrativa da mulher que virou jaú, sua irmã mais nova ficou interessada e pediu para acompanhá-la até o fundo do rio. Seu pedido foi aceito com uma condição, a de se comportar respeitando o rio como uma morada e não olhar os peixes apenas como alimentação. Chegando lá, dentro do rio, a irmã mais nova da mulher se

44 IRIGARAY, C. T. H. Do estado de guerra ao estado de bem-estar ambiental: contribuição indígena ao contrato de armistício. Revista de Estudos Sócio-Jurídico-Ambientais Amazônia Legal, v. 2, p. 67-101, 2007. Este autor esclarece que tomou conhecimento desta estória por meio da tradução não publicada que Reginaldo Ikaura, Vânia Ataiwalo e Valdenor Aigore fizeram do texto de Apolônio Apiaga, escrito na língua Kura. 
esqueceu da recomendação e foi logo catando os lambaris, para assá-los, comendo também as arraias, isso significava destelhar as casas e quebrar as panelas. Envergonhada a mulher trouxe de volta a sua irmã e passou a morar para sempre no fundo do rio.

Para além de um mero conto ou passagem folclórica, eis aí um fator sociocultural que perpassa e organiza o modo como este povo lida com o rio. Embora despidos de termos técnicos e justificativas "cientificas", estes ensinos, transmitidos e perpetuados de geração em geração, corporificam uma racionalidade visceralmente sustentável, forjada na interação viva da cultura com as práticas sociais de apropriação dos bens ambientais, cujo valor transcende a mera utilidade pragmática para repousar na dignidade da vida em si.

Portanto, é razoável a afirmação de que há uma intrínseca relação entre a conservação da biodiversidade e manutenção do equilibrio ecológico do Pantanal e os modos de ser, fazer e viver das populações tradicionais e etnias indígenas que o habitam, de forma que esta complexa interação configura um bem socioambiental cuja proteção encontra-se constitucionalmente positivada. Disso resulta que, por força do marco jurídico-constitucional socioambiental, o termo "ecologicamente sustentável", constante do art. 10 da Lei n. 12.651/2012, para além de uma concepção estritamente naturalista, deve ser interpretado com vistas à articulação dos fatores sociais, políticos, ecológicos e culturais que integram a noção de sustentabilidade.

Já no que se refere às "recomendações técnicas" com base nas quais deverão se desenvolver as atividades de exploração das áreas aludidas no art. 10 do Novo Código Florestal, pode-se indagar: são somente os órgãos oficiais de pesquisa que detêm legitimidade para tanto, ou é possível que as sociedades tradicionais participem do processo de elaboração destas recomendações?

De início, há que se destacar que a razão de ser destas recomendações é justamente o estabelecimento de critérios delimitadores das possibilidades de exploração dessas áreas.

Logo, éfundamental que os parâmetros adotados considerem as peculiaridades do Pantanal. E não só as peculiaridades ecológicas — como a dinâmica do pulso de inundação e sua relação com os planaltos e chapadões circunvizinhos, por exemplo - , mas também os fatores socioculturais direta e indiretamente associados, pois se trata de um bioma que compreende riquíssima sociobiodiversidade, configurando assim um bem socioambiental que deve ser zelado pelo Estado e por toda a coletividade para que as presentes e futuras gerações possam desfrutá-lo. 
A princípio, parece bem plausível que os critérios de exploração sejam elaborados com base em teorias cientificas metodologicamente consistentes, neste caso, desenvolvidas pelos órgãos oficiais de pesquisa. Diante disso, aparenta ser irrisório ou até mesmo inexpressivo o valor do conjunto dos conhecimentos tradicionais gestados, cultivados e perpetuados pelas sociedades tradicionais, uma vez que um dos traços fundamentais destes conhecimentos seria a visão empírica, mítica e folclórica da natureza, cuja apropriação e utilização dar-se-iam sem qualquer método nem racionalidade.

Contudo, embora um dos caracteres distintivos da modernidade seja o fato de o discurso cientifico se arvorar na condição de único conhecimento válido para a eficiente intervenção sobre a realidade, relegando ou até mesmo anulando todas as demais formas de conhecimento ${ }^{45}$, recentemente esta ideia tem sido colocada em xeque.

Primeiro porque se torna cada vez mais evidente que as formulações das diversas matrizes teóricas que se inscrevem neste discurso não se encontram tão isentas de variáveis políticas e econômicas como pretendem seus cultores e defensores ${ }^{46}$. Segundo porque a própria eficácia e controlabilidade dos resultados práticos da tecnociência têm demonstrado que a realidade é bem mais complexa do que pressupunham os modelos cientificos elaborados a partir de experiências de laboratório. ${ }^{47}$

Isto é cada vez mais notório, sobretudo no que se refere ao meio ambiente, porquanto grande parte dos desequilibrios ecológicos experimentados por significativas parcelas da população mundial decorre diretamente dos indesejáveis efeitos de grandes empreendimentos (grandes projetos de hidrelétricas, hidrovias, usinas nucleares, desflorestamento de áreas verdes para a implantação

45 A este respeito, Santos nos lembra que "A história canónica da ciência ocidental é uma história dos alegados - e, sem dúvida, reais - benefícios e efeitos capacitantes que a ciência moderna, através do desenvolvimento tecnológico ou dos avanços no domínio da medicina, por exemplo, terá trazido às populações de todo o mundo. Mas o outro lado da história - os epistemicídios que foram perpetrados, em nome da visão científica do mundo, contra outros modos de conhecimento, com o consequente desperdício e destruição de muita da experiência cognitiva humana - é raras vezes mencionado e, quando tal acontece, é-o sobretudo para reafirmar a bondade intrínseca da ciência e opô-la às aplicações perversas desta por actores económicos, políticos e militares poderosos, que seriam, esses sim, responsáveis pelos "maus" usos de uma ciência intrinsecamente indiferente a considerações morais e de um conhecimento que, em si mesmo, teria uma vocação benigna. A história da ciência, contudo, é feita tanto dos seus sucessos e dos seus benefícios como dos seus efeitos e consequências perversos ou negativos. Uns e outros podem, também, ser avaliados e narrados a partir de posições distintas e de experiências históricas diferentes - do cientista ou do leigo, do colonizador ou do colonizado. A recuperação ou reconstrução dessas "outras" versões da história da ciência é hoje indispensável para que esta deixe de ser a história da emergência e expansão da ciência ocidental moderna e passe a abrir novos caminhos para histórias globais e multiculturais do conhecimento, superando assim o que tem sido designado por colonialidade do saber". In: SANTOS, Boaventura de Souza; MENEZES, Maria Paula G.; NUNES, João Arriscado. Conhecimento e transformação social: por uma ecologia de saberes. In: Hiléia: Revista de Direito Ambiental da Amazônia, ano 4, n. 6. p. 15, 2006. Manaus: Edições Governo do Estado do Amazonas / Secretaria de Estado da Cultura / Universidade do Estado do Amazonas.

46 SANTOS et al., op. cit., p. 13-14.

47 Idem, Ibidem, p. 14-15. 
de monocultivos com intenso uso de agrotóxicos, etc.) implementados sob os auspícios da tecnociência a serviço do capital. Assim, os resultados concretos da intervenção humana - cientificamente lastreada — sobre a natureza têm se revelado bem menos previsíveis e controláveis do que apregoa o discurso hegemônico.

Nessa linha, valendo-se das considerações de Anthony B. Rylands ${ }^{48}$ acerca dos subsídios do discurso cientifico para a conservação da biodiversidade, Diegues $^{49}$ pondera que:

[...] a contribuição das ciências naturais para a conservação ainda está em seu início, e muitos de seus pressupostos são discutíveis. Por exemplo, nos anos 70 adotou-se a teoria dos refúgios do pleitoceno para se definir as áreas naturais a serem conservadas na Amazônia brasileira. Hoje esse critério está sendo questionado, o que significa que, de acordo com outras teorias, as áreas já estabelecidas como unidades de conservação amazônicas talvez não sejam as mais adequadas para se proteger a biodiversidade.

Assim, pode se aduzir que o discurso científico talvez não seja, por si só, apto o suficiente para garantir a conservação da biodiversidade de florestas e outros biomas, tanto mais quando se tratar de territórios que além de biodiversos compreendam um amplo espectro de sociedades tradicionais, como no caso do Pantanal.

Ora, não se está a negar nem menoscabar os inúmeros avanços e benefícios oriundos das teorias e descobertas científicas com base nas quais formularam-se modelos razoáveis de explicação e intervenção sobre espaços naturais, ensejando a melhora da qualidade de vida de populações urbanas e rurais.

Contudo, os conhecimentos tradicionais - embora no mais das vezes metodologicamente dissonantes do que preconiza o discurso científico — também possuem validade e utilidade, não só para os membros das sociedades que o cultivam, mas para toda a humanidade, na medida em que apontam caminhos viáveis para a superação de problemas ainda não resolvidos ou sequer suspeitados pela comunidade cientifica.

Eis o caso da biodiversidade.

48 RYLANDS, A. Protected Areas in Brazilian Amazônia. In: Atlas do Congresso Internacional: On Common Ground. Belo Horizonte, 1993.

49 DIEGUES, Antônio Carlos. O mito moderno da natureza intocada. São Paulo: Editora Hucitec, 2008. p. 74. 
A propósito, Calheiros et al., pesquisando as causas e efeitos da "dequada" 50 no Pantanal, valendo-se da percepção de alguns moradores locais (ribeirinhos pescadores) acerca deste fenômeno, concluíram que:

Os moradores da Baía do Castelo detêm um grande conjunto de conhecimentos relativos às causas, indicadores e impactos observáveis sobre a dequada em sua comunidade. Em um certo número de casos, em particular o comportamento dos peixes, localização do fenômeno, e as espécies mais comumente afetadas, o conhecimento local se mostrou superior ao da comunidade científica. A incorporação do conhecimento local aperfeiçoou o desempenho da pesquisa limnológica em termos de qualidade e eficiência, corroborando a importância de algumas variáveis teoricamente previstas, eliminando outras, e abrindo novos campos de pesquisa. A metodologia facilitou a constatação de importantes variáveis locais e significativas complexidades contextuais, sem as quais seria maior a possibilidade de interpretações equivocadas dos resultados ${ }^{51}$.

Verifica-se, então, que o discernimento das populações tradicionais acerca de fenômenos naturais que ocorrem nos espaços que habitam e manejam há gerações pode contribuir sobremaneira para o avanço de pesquisas cientifícas e formulação de estratégias para a mitigação e superação de problemas ecológicos.

Nesse sentido, Calheiros et al. apontam que a incorporação dos conhecimentos tradicionais nas pesquisas cientificas levadas a efeito nos locais ha-

50 "[...] fenômeno natural de deterioração da qualidade da água, denominado regionalmente como 'Dequada', relacionado à decomposição da grande massa de matéria orgânica submersa no início do processo de inundação. Sua magnitude é dependente das características do pulso de inundação, ou seja, características da fase de seca anterior e do período de inundação subsequente (volume e velocidade). De acordo com essa magnitude, pode provocar mortandade massiva de peixes (podendo alcançar a ordem de milhares de toneladas), decorrente da depleção de oxigênio e do aumento da concentração de gás carbônico, resultantes dos processos de oxidação da matéria orgânica, tanto nos campos inundados, quanto na coluna d'água dos rios". In: CALHEIROS, Debora Fernandes; FERREIRA, Celso João Alves. Alterações limnológicas no rio Paraguai ("dequada") e o fenômeno natural de mortandade de peixes no Pantanal Mato-GrossenseMS. Corumbá: Embrapa-CPAP, 1996. p. 4. Disponível em: < http://ainfo.cnptia.embrapa.br/digital/bitstream/ item/37450/1/BP07.pdf > Acesso em: 13 abr. 2016.

51 "The residents of Baía do Castelo maintain a great store of knowledge regarding the causes, indicators and observable impacts of dequada in their community. In a number of cases, in particular fish behaviour, location of the phenomenon, and the most commonly affected fish species, local knowledge was found to be superior to that of the scientific community. The incorporation of local knowledge improved the performance of the limnological research on quality and efficiency dimensions by corroborating the importance of some theoretically prescribed variables, eliminating others, and raising new dimensions for research consideration. The methodology facilitated the discovery of locally important variables and significant contextual complexities, the absence of which would have increased the likelihood of erroneous interpretation of results." Tradução livre. In: CALHEIROS, D. F.; SEIDL, A. F.; FERREIRA, C. J. A. Participatory research methods in environmental science: local and scientific knowledge of a limnological phenomenon in the Pantanal wetland of Brazil. In: Journal of Applied Ecology, 2000, v. 37, p. 684-696. Disponivel em: < http://dx.doi.org/10.1046/j.13652664.2000.00524.x > Acesso em: 22 abr. 2016. 
bitados por estas populações resulta em vários benefícios, dentre os quais o fato de os moradores locais se sentirem respeitados e valorizados, buscando colaborar mais ativamente com as políticas definidas com base nos processos de investigação dos quais participaram. ${ }^{52}$

A despeito disso, a maior parte das políticas e projetos de conservação implementados pelos órgãos de Estado tem se pautado na maioria das vezes por interesses econômicos, e, quando muito, única e exclusivamente pelas considerações oferecidas pelo discurso científico, em total desprezo às possíveis contribuições dos conhecimentos tradicionais.

Configura-se assim uma disputa perpassada por fatores políticos e epistemológicos:

De um lado, está o saber acumulado das populações tradicionais sobre os ciclos naturais, a reprodução e migração da fauna, a influência da lua nas atividades de corte da madeira, da pesca, sobre os sistemas de manejo dos recursos naturais, as proibições do exercício de atividades em certas áreas ou períodos do ano, tendo em vista a conservação das espécies. De outro lado, está o conhecimento científico, oriundo das ciências exatas que não apenas desconhece, mas despreza o conhecimento tradicionalmente acumulado. Em lugar da etnociência, instala-se o poder da ciência moderna, com seus modelos ecossistêmicos, com a administração "moderna" dos recursos naturais, com a noção de capacidade de suporte baseada em informações científicas (na maioria das vezes, insuficientes)..$^{53}$

Os reflexos deste debate apontam a premência do discurso científico sobre os conhecimentos tradicionais, mormente nas esferas institucionais (principalmente Embrapa, Ibama e órgãos estaduais de meio ambiente) responsáveis pela elaboração das diretrizes atinentes à utilização de recursos naturais, conservação da biodiversidade e concessão de licenças de uso e exploração.

A concretude dos desdobramentos políticos deste embate torna-se ainda mais evidente quando se leva em conta o fato de que muitas vezes as sociedades tradicionais são surpreendidas por medidas preservacionistas restritivas e autoritárias, que em nome do equilibrio ecológico e manutenção da biodiversidade limitam seus modos de ser, fazer e viver, ou ainda preveem sua retirada dos

$\overline{52 \text { Idem, Ibidem. }}$

53 DIEGUES, op. cit., p. 71. 
espaços que habitam e manejam há várias gerações, como ocorre no processo de criação das Unidades de Conservação de Uso Restrito. ${ }^{54}$

Este quadro sobreleva a correlação existente entre os princípios democráticos e a proteção dos bens socioambientais, uma vez que o:

Socioambientalismo que permeia a Constituição privilegia e valoriza [...] a transversalidade das políticas públicas socioambientais [...] e a consolidação de processos democráticos de participação social na gestão ambiental. 55

Nesse sentido, Morato e Ayala ${ }^{56}$ afirmam que:

Na construção do Estado democrático, na vertente ambiental, deve imperar um sistema legislativo que viabilize a coletividade a participar das decisões ambientais, a obter informações indispensáveis para a tomada de consciência e emitir opiniões sobre o tema.

Dantas, por sua vez, ressalta que:

O novo paradigma constitucional do sujeito diferenciado indígena e suas sociedades [...] constitui um dos caminhos para a construção de uma sociedade plural, em que o espaço para todos seja garantido e, consequentemente, o dissenso possibilite o exercício cotidiano da democracia participativa e do seu poder instituinte sempre renovado..$^{57}$

Nessa tessitura jurídico-política, a sustentabilidade implica diretamente a ideia de democratização dos processos decisórios, mormente no que atinem à gestão dos espaços sociobiodiversos, posto que: "Fazer das camadas populares sujeitos políticos de seu ambiente material, social, econômico e cultural [...] é o desafio da construção da sustentabilidade democrática em nosso país". ${ }^{58}$

Nesse passo:

[...] o desenvolvimento sustentável deve integrar as diferentes formações socioeconômicas e grupos étnicos de uma nação, e implica a participação das comunidades na percepção, gestão e manejo de seus recursos..$^{59}$

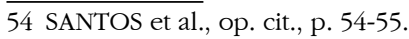

55 SANTILLI, op. cit., p. 60.

56 MORATO LEITE, José Rubens; AYALA, Patryck de Araújo. Dano Ambiental: do individual ao coletivo extrapatrimonial. Teoria e prática. 6. ed. São Paulo: Editora Revista dos Tribunais, 2014. p. 49.

57 DANTAS, op. cit.

58 ACSELRAD, Henri; LEROY, Jean-Pierre. Novas premissas da Sustentabilidade democrática. s/d. Disponível em: < http://www.educacaoambiental.pro.br/victor/biblioteca/AcselradLeroyNovasPremissas.pdf > Acesso em: 12 fev. 2016.

59 LEFF, Henrique. Saber Ambiental: sustentabilidade, racionalidade, complexidade e poder. Petrópolis: Editora
} 
Portanto, nos moldes do marco jurídico-constitucional socioambiental afigura-se-nos justo e coerente que também as comunidades tradicionais e povos indígenas participem da formulação dos critérios definidores das possibilidades de exploração das áreas referidas no art. 10 do Novo Código Florestal. ${ }^{60}$

A propósito, constitui um dos objetivos específicos da Política Nacional de Desenvolvimento Sustentável dos Povos e Comunidades Tradicionais:

I - garantir aos povos e comunidades tradicionais seus territórios, e o acesso aos recursos naturais que tradicionalmente utilizam para sua reprodução física, cultural e econômica (Art. $3^{\circ}$, inc. I, da Política Nacional de Desenvolvimento Sustentável dos Povos e Comunidades Tradicionais).

Além disso, esta mesma Política Nacional adota como princípio:

$\mathrm{X}$ - a promoção dos meios necessários para a efetiva participação dos Povos e Comunidades Tradicionais nas instâncias de controle social e nos processos decisórios relacionados aos seus direitos e interesses (Art. $1^{\circ}$, inc. X, da Política Nacional de Desenvolvimento Sustentável dos Povos e Comunidades Tradicionais).

A seu turno, nos termos dos incisos XII e XIII do art. $3^{\circ}$ da Lei Estadual $n$. 8.830/2008, a Política Estadual de Gestão e Proteção à Bacia do Alto Paraguai no Estado de Mato Grosso balizar-se-á, dentre outros, pelos seguintes princípios: XII - reconhecimento dos saberes tradicionais como contribuição para o desenvolvimento e gestão das potencialidades da região;

XIII - respeito e valorização às formas de uso e gestão dos bens ambientais utilizados por povos e comunidades tradicionais.

Por sua vez, a Política Nacional de Recursos Hídricos, instituída pela Lei n. $9.433 / 1997$, preceitua no art. $1^{\circ}$, inciso VI que:

VI - a gestão dos recursos hídricos deve ser descentralizada e contar com a participação do Poder Público, dos usuários e das comunidades.

Vozes, 2001. p. 141.

60 Aliás, por ocasião da $7^{a}$ Reunião das Partes Signatárias da Convenção de Ramsar, realizada em 1999, na Costa Rica, restou consignado que a implementação das estratégias de fortalecimento da participação das comunidades locais e dos povos indígenas na gestão das áreas úmidas deve partir da premissa de que "O envolvimento destas comunidades na gestão das áreas úmidas pode contribuir substancialmente para a consecução das práticas de 'uso racional', detalhadas na Convenção de Ramsar. Como definido na Ramsar COP 3 (1987), 'uso racional das áreas úmidas significa a utilização sustentável para o benefício da humanidade de um modo compatível com a manutenção das propriedades naturais do ecossistema'. Evidências de 23 estudos de caso encomendados e outras experiências de gestão participativa indicam que o envolvimento de indígenas e habitantes locais, se levado a efeito de acordo com a estrutura de ações propugnada pela Convenção, pode contribuir significativamente para manter ou restaurar a integridade ecológica das áreas úmidas, bem como contribuir para o bem-estar da população e propiciar um acesso mais igualitário aos recursos. Em termos práticos, o conceito de 'uso racional' utilizado pela Convenção de Ramsar equivale a 'uso sustentável'". Tradução livre. Disponível em: < http://www.ramsar.org/sites/default/files/documents/ cOp7-docs/NON-RESRECS\%20FINAL/COP7\%2017.1E.pdf > Acesso em: 22 abr. 2016. 
A leitura conjugada destes dispositivos, sistematicamente interpretados à luz dos preceitos socioambientais constitucionalmente consagrados, embasa a assertiva de que os órgãos oficiais de pesquisa deverão levar em consideração as contribuições dos conhecimentos tradicionais na formulação das recomendações técnicas com base nas quais serão desenvolvidas as atividades de exploração das áreas referidas no art. 10 da Lei n. 12.651/2012.

Nessa linha, Diegues ${ }^{61}$ preleciona que:

[...] as instituições de pesquisa e de gestão desses ambientes se defrontam com o grande desafio de fazer uma análise crítica dos modelos de conhecimento e gestão ainda hoje utilizados e propor novas alternativas de conservação que sejam mais democráticas e participativas, que beneficiem a conservação da biodiversidade e da diversidade cultural, mais interdisciplinares e intensivas em ciência e conhecimentos tradicionais, resultando numa proteção mais eficaz dos habitats e numa melhoria de vida das comunidades humanas que vivem na floresta, na zona costeira, às margens de rios e lagos brasileiros.

Não obstante se refiram especificamente às Unidades de Conservação, estas considerações aplicam-se perfeitamente ao cenário do Pantanal no contexto da implementação do preceito inscrito no art. 10 do Novo Código Florestal.

Este dispositivo, assim, deve ser interpretado e aplicado de modo a realizar ao máximo os preceitos socioambientais emanados da Constituição de 1988, mormente no que atine à construção de processos decisórios democráticos, em que cientistas, gestores e populações tradicionais possam dialogar e ativamente participar da formulação e implementação de políticas públicas tendentes à promoção de uma gestão socioambientalmente sustentável do Pantanal, porquanto:

[...] a construção de um futuro sustentável requer um diálogo aberto, capaz de acolher visões e negociar interesses contrapostos na apropriação da natureza; mas esse diálogo não produzirá consensos baseados em visões homogêneas, nem se limitará a negociar conflitos emergentes. O diálogo de saberes abre suas comportas a partir do reconhecimento dos saberes - autóctones, tradicionais, locais - que contribuem com suas experiências e se somam ao conhecimento cientifico e especializado; mas implica, por sua vez, a dissensão e a ruptura de um caminho

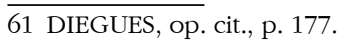


homogêneo para a sustentabilidade; é a abertura para a diversidade que rompe as barreiras da reclusão da lógica unitária hegemônica para permitir a inclusão de visões alternativas e a participação de racionalidades diversas na heteronomia da linguagem e em uma política da diferença. ${ }^{62}$

Assim, conquanto o Novo Código Florestal tenha representado, em certa medida, um retrocesso em termos de proteção ambiental (designadamente no que tange aos critérios de definição das APPs), o ordenamento jurídico brasileiro, conformado à luz dos preceitos socioambientais articulados ao princípio da sustentabilidade, fornece elementos normativos a partir dos quais pode-se trilhar caminhos hermenêuticos tendentes à consecução de propostas de gestão socioambientalmente sustentáveis.

Eis o caso do art. 10 da Lei n. 12.651/2012, cuja redação, não obstante textualmente inadequada, permite a elaboração de normas jurídicas aptas a garantir a democratização dos processos decisórios concernentes à elaboração dos critérios com base nos quais se desenvolverão as atividades de exploração das áreas referidas neste dispositivo, especialmente o Pantanal Mato-grossense.

\section{Considerações Finais}

Por sua peculiar biodiversidade somada ao amplo espectro de manifestações socioculturais que abriga, o Pantanal se apresenta como um incomensurável bem socioambiental, excepcionalmente importante para toda a humanidade, tanto para as presentes como para as futuras gerações.

Não obstante o texto constitucional confira-lhe uma especial proteção, esta não tem se verificado concretamente, mormente diante da vagueza e inadequação dos preceitos legais aplicáveis a este bioma, que segue sofrendo graves danos ambientais.

Neste sentido, a entrada em vigor do Novo Código Florestal acarretou diversos retrocessos em termos de proteção ambiental, designadamente em relação aos critérios de definição de APPs. O Pantanal, neste contexto, foi sensivelmente atingido na medida em que áreas deste bioma que no antigo regime legal eram consideradas APPs passaram a poder ser exploradas economicamente.

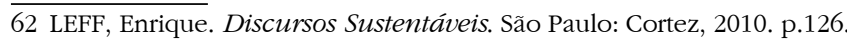


Contudo, nos termos do marco jurídico-constitucional socioambiental é possível a formulação de caminhos hermenêuticos consoantes às necessidades de proteção deste bioma, tanto no que concerne à conservação da biodiversidade e dos serviços ecológicos, quanto no que toca à preservação das condições indispensáveis para a produção e reprodução dos modos de ser, fazer e viver das sociedades tradicionais que habitam o Pantanal.

Assim, a regra inscrita no art. 10 do Novo Código Florestal, embora a princípio textualmente inadequada para este propósito, pode engendrar interpretações propícias à promoção de uma gestão mais sustentável do Pantanal.

Para tanto, mais do que um locus de grande biodiversidade, este espaço deve ser enxergado como um complexo conjunto de ecossistemas cujas intrincadas relações hidro-ecológicas encontram-se intimamente ligadas à digna existência das sociedades tradicionais que sustentavelmente o habitam e o preservam com base em conhecimentos milenares.

Muito além de folclore, estes conhecimentos e habilidades refletem uma rica sabedoria que, se articulada aos métodos científicos na consecução de políticas públicas, resultará em possibilidades reais de construção de um arranjo político e social pluralista e democrático, deveras apropriado para a preservação integrada do meio ambiente e das culturas tradicionais associadas.

\section{Referências}

ACSELRAD, Henri; LEROY, Jean-Pierre. Novas premissas da Sustentabilidade democrática. s/d. Disponível em: $<$ http://www.educacaoambiental.pro.br/victor/biblioteca/AcselradLeroyNovasPremissas.pdf $>$ Acesso em: 12 fev. 2016.

AFONSO DA SILVA, José. Curso de Direito Constitucional Positivo. 16. ed. Brasil, 1999.

CALHEIROS, Débora Fernandes; OLIVEIRA, Márcia Divina de. O rio Paraguai e sua planície de inundação: o Pantanal Mato-grossense. In: Ciência e Ambiente, n. 41, p. 121, jul./dez. 2010.

CALHEIROS, D. F.; SEIDL, A. F.; FERREIRA, C. J. A. Participatory research methods in environmental science: local and scientific knowledge of a limnological phenomenon in the Pantanal wetland of Brazil. In: Journal of Applied Ecology, v. 37, p. 684-696, 2000. Disponível em: < http://dx.doi.org /10.1046/j.1365-2664.2000.00524.x> Acesso em: 22 abr. 2016.

DANTAS, Fernando Antonio de Carvalho. Os povos indígenas brasileiros e a "Cidadania Ativa". Revista Argumenta Journal Law, Jacarezinho - PR, n. 5, p. 180-194, fev. 2013. Disponível em: < http://seer. uenp.edu.br/index.php/argumenta/article/view/46 > Acesso em: 10 abr. 2016.

DIEGUES, Antônio Carlos; ARRUDA, Rinaldo S.V. (Org.). Saberes tradicionais e biodiversidade no Brasil. Brasilia: Ministério do Meio Ambiente; São Paulo: USP, 2001.

DIEGUES. Antônio Carlos. O mito moderno da natureza intocada. São Paulo: Editora Hucitec, 2008. 
DOUROJEANNI, Marc J. Construindo o futuro do Pantanal. Rio de Janeiro: SESC, 2006.

FERRAZ JR, Tércio Sampaio. Constituinte: Assembleia, Processo, Poder. São Paulo: Revista dos Tribunais, 1985.

FREITAS, Juarez. Sustentabilidade: direito ao futuro. Belo Horizonte: Fórum, 2012.

IRIGARAY, C. T. H.; DA SILVA, Carolina Joana; MEDEIROS, Heitor Queiroz; GIRARD, Pierre; FAVA, Gustavo Crestani; MACIEL, J. C.; GALLO, Rogério Luis; NOVAIS, Lafayette Garcia. O Pantanal Matogrossense enquanto patrimônio nacional no contexto das mudanças climáticas. In: SILVA, Solange; CUREAU, Sandra; LEUZINGER, Márcia. (Org.). Mudança do Clima. Desafios jurídicos, econômicos e socioambientais. 1. ed. São Paulo: Fiuza, 2011. .

IRIGARAY, C. T. H. Do estado de guerra ao estado de bem-estar ambiental: contribuição indígena ao contrato de armistício. Revista de Estudos Sócio-Jurídico-Ambientais Amazônia Legal, v. 2, p. 67-101, 2007.

IRIGARAY, C. T. H. Pagamento por serviços Ecológicos e o Emprego do REDD na Amazônia. In: LAVRATTI, Paula; PRESTES, Vanêsca Buzelado. (Org.). Direito e Mudanças Climáticas 3. Serviços Ecológicos. 1. ed., 2010. v. 1, p. 9-38.

LEFF, Enrique. Discursos Sustentáveis. São Paulo: Cortez, 2010.

LEFF, Henrique. Saber Ambiental: sustentabilidade, racionalidade, complexidade e poder. Petrópolis: Vozes, 2001.

MAPA de Cobertura Vegetal dos Biomas Brasileiros. Disponível em: < http://www.mma.gov.br/ estruturas/sbf chm rbbio/arquivos/mapas cobertura vegetal.pdf > Acesso em: 20 jan. 2016.

MARÉS DE SOUZA FILHO, Carlos Frederico. Introdução ao direito socioambiental. In: LIMA, André (Org.). O direito para o Brasil socioambiental. São Paulo: Instituto Socioambiental; Porto Alegre: Sérgio Antônio Fabris, 2002.

MORATO LEITE, José Rubens; AYALA, Patryck de Araújo. Dano Ambiental: do individual ao coletivo extrapatrimonial. Teoria e prática. 6. ed. São Paulo: Editora Revista dos Tribunais, 2014.

NETO, José Pereira de Queiroz. Pantanal, Pantanais: Patrimônio Nacional. In: RIBEIRO, Wagner Costa (Org.). Patrimônio Ambiental Brasileiro. São Paulo: Editora da Universidade de São Paulo: Imprensa Oficial, 2003.

PIEDADE, Maria Teresa; JUNK, Wolfgang J.; SOUZA JR, Paulo Teixeira; DA CUNHA, Catia Nunes; SCHÖNGART, Jochen; WITTMAN, Florian; GIRARD, Pierre. As áreas úmidas no âmbito do Código Florestal brasileiro. In: LIMA, André et al (Coords.). Código Florestal e a ciência: o que nossos legisladores ainda precisam saber. Sumários executivos de estudos científicos sobre impactos do Projeto do Código Florestal. Brasilia: Comitê Brasil em defesa das florestas e do desenvolvimento sustentável, 2012.

PURVIM FIGUEIREDO, Guilherme José. Capítulo 1. Art. 1. In: MILARÉ, Édis; LEME MACHADO, Paulo Afonso (Coord.). Novo código florestal: comentários à Lei 12.651, de 25 de maio de 2012, à Lei 12.727, de 17 de outubro de 2012 e do Decreto 7.830, de 17 de outubro de 2012. 2. ed. São Paulo: RT, 2013.

RESENDE, Emiko Kawakami de. Pulso de inundação: processo ecológico essencial à vida do Pantanal. Corumbá: Embrapa Pantanal, 2008.

RYLANDS, A. Protected Areas in Brazilian Amazônia. In: Atlas do Congresso Internacional: On Common Ground. Belo Horizonte, 1993. 
SANTILLI, Juliana. Socioambientalismo e novos direitos: proteção jurídica à diversidade biológica e cultural. São Paulo: Editora Peirópolis, 2005.

SANTOS, Boaventura de Sousa; MENESES, Maria Paula. (Orgs.) Epistemologias do Sul. São Paulo: Cortez, 2010.

SANTOS, Boaventura de Souza; MENEZES, Maria Paula G.; NUNES, João Arriscado. Conhecimento e transformação social: por uma ecologia de saberes. Hiléia: Revista de Direito Ambiental da Amazônia, ano 4, n. 6. Manaus: Edições Governo do Estado do Amazonas / Secretaria de Estado da Cultura / Universidade do Estado do Amazonas, 2006.

SARLET, Ingo Wolfgang; FENSTERFEIFER, Tiago. Direito Constitucional Ambiental: Constituição, Direitos Fundamentais e Proteção do Meio Ambiente. 3. ed. São Paulo: Editora Revista dos Tribunais, 2013.

SARLET, Ingo Wolfgang; FENSTERFEIFER, Tiago. Estado socioambiental e mínimo existencial (ecológico?): algumas aproximações. In: SARLET, Ingo Wolfgang (Org.) Estado Socioambiental e Direitos Fundamentais Porto Alegre: Livraria do advogado, 2010.

SILVA, Carolina Joana; NUNES, José Ribeiro da Silva; SIMONI, Jane. O sistema de Baías Chacororé Sinhá Mariana. In: SILVA, Carolina Joana da; SIMONI, Jane. (Org.). Água, biodiversidade e cultura do Pantanal: estudos ecológicos e etnobiológicos no sistema de Baías Chacororé - Sinhá Mariana. Cáceres: Ed. UNEMAT, 2012.

THE NATURE Conservancy; WWF-Brasil. Análise de risco ecológico na Bacia do Rio Paraguai - Argentina, Bolivia, Brasil e Paraguai. 1. ed. Brasilia, 2012. 